Staneva, T. (2021). Fundamentals of dance training in the system of secondary education in Varna. Culture and arts in the context of cultural heritage. Klironomy, 3 (3), 150-165. Hlučín-Bobrovníky: "Anisiia Tomanek" OSVČ. (in Bulgarian)

Станева, Т. (2021). Основите на танцовото обучението в системата на средното образование във Варна. Culture and arts in the context of cultural heritage. Klironomy, 3 (3), 150-165. Hlučín-Bobrovníky: "Anisiia Tomanek" OSVČ.

DOI: $10.47451 /$ art2021-10-003

EOI: $10.11249 / \operatorname{art} 2021-10-003$

The paper is published in Crossref, Internet Archive, ICI Copernicus, Google Scholar, Academic Resource Index ResearchBib, JGate, ISI, CiteFactor, Journal Factor, eLibrary, Ukrainian National Library databases.

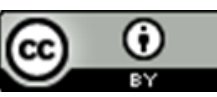

Teodora Staneva

Assistant

Department of Arts

Faculty of Architecture

Varna Free University "Chernorizets Hrabar"

Varna, Bulgaria

E-mail: teodora.staneva@vfu.bg

\title{
Fundamentals of dance training in the system of secondary education in Varna
}

\section{Abstract:}

This article examines the foundation as well as the current conditions of dance education in the system of secondary education in Varna. The city is an international cultural center and is the first non- principal city to implement vocational ballet education. In 1964, the world's first international ballet competition was held in Varna, which has granted the city a historic place in the thousands of years of cultural history of the world. The main source of information on the highly effective pedagogical practices of Galina and Stefan Yordanovi is an in-depth analysis of data collected from periodical press in the period 1965-1985. Their views on the development of dance training and methodology are covered mostly by local journalists in Varna. The focus of this paper is Stefan Yordanov's extremely valuable article on vocational ballet education in Varna, published in Narodno Delo. In an attempt to reconstruct the history of art dance education in Varna with the authenticity of the shared ideas, these materials can serve as sources for an essential part of the yet unwritten history. This work is part of an overall study on teaching dance as art in secondary education in Bulgaria.

Keywords: dance, education, ballet, training, choreography, dance art.

Теодора Станева

Асистент

катедра „Изкуства“

Архитектурен факултет

Варненски свободен университет „Черноризец Храбър“ 
Варна, Бъцгария

E-mail: teodora.staneva@vfu.bg

\section{Основите на танцовото обучението в системата на средното образование във Варна}

Резюме:

В статията се проследяват основите и условията за танцово обучението в системата на средното образование във Варна. Варна е международен културен центьр в сферата на танца, където се заражда първото извън столично професионално балетно образование. Провеждането през 1964 година на първия в света международен балетен конкурс отрежАат място на Бъмгария и на Варна в хилядолетната културна история. Изследването на информация от периодичния печат е периода 1965-1985 година е основен източник за успешната педагогическата дейност на Галина и Стефан Йорданови. Техните възгледи за развитието на танцовото обучение и методика се отразяват предимно от варненски журналисти. Акцент в проучването е изключително ценната авторска статия на Стефан Йорданов поместена в в-к “Народно Аело” по повод професионалното балетно образование във Варна. В опит за реконструиране на историята на художественото танцово образование във Варна с автентичността на споделените илеи, тези материали могат Аа послужат за източници на една съществена част от ненаписаната история. Материала е част от цялостното изследване на обучението по танцово изкуство в сферата на средното образование в Бъмгария.

Ключови думи: танц, балет, образование, обучение, хореография, танцово изкуство.

\section{Въведение}

Съществено постижение в културния живот на граА Варна е създаването на Международният музикален фестивац "Варненско мято”. Той се обогатява с провеждането на първия по рода си Международен балетен конкурс, а Аетният театьр се превръща в емблематичното пространство на световно балетно състезание. Утвърждаването на Варна като световен балетен центьр, трябва да се защити със завидна балетна култура. Това е елна от задачите, която поставят пред себе си на Галина и Стефан Йорданови, инициатори на първото извън столично професионално балетно образование. Тяхната цел е създаването на млади кадри, които непрекъснато да обновяват основния балетен състав при операта. С Откриването на експериментален клас към Аържавното хореографско училище в София (1966 г.), а по-късно и клас към НУИ “Аобри Христов” във Варна, те поставят основите на професионалното танцово образование във Варна и перспективата тоя опит да се превърне в традиция. Следват световната традиция, големите оперни и балетни театри да 
имат собствени студия-училища за подготовка на каАри. Аа се създадат висококвалифицирани изпълнители, с единен стил.

Целта на настоящото изследване е Аа се съхрани и Аокументира културното и историческо наследство, оставено от Галина и Стефан Йорданови. Аа се съхранят техните идеи, творчески тьрсения и постижения в областта на танцовото изкуство. Аа се съхрани историческата памет за приноса им и тяхната роля в цялостното реконструиране на историята на художественото танцово образование във Варна.

Задачите свързани с осъществяването на поставената цел вкцючват:

- изследване на материали от периодичния печат, за да се документира “неписаната история” на извън столичното професионацно танцовото образование в България ;

- $\quad$ проследяване на предпоставките и процеса на зараждане и създаване на експериментални танцови класове;

- на база изследваните материали да се реконструирана зараждането на художественото танцово образование във Варна.

В съответствие със задачите и спецификата на предмета на изследване са използвани методи на теоретичното познание: използван е метод на анализ на основата на който са изведени съдържание и специфика на изследвания проблем, исторически изследователски метод за проследяване на хронологията на педагогическата дейност на Галина и Стефан Йорданови. Емпиричен изследователски метод - проучване на текстови източници с цел реконструиране на художествените им биографии. Подбор на фотоматериали, които документират анализа.

Педагогическата дейност на Галина и Стефан Йорданови е отразявана преАимно от варненски журналисти. Именно тези материали са използвани като основен източник на информация. Преобладават журналистическите жанрове, които са Аиалогични: разговор, интервю, репортаж. Макар и не много на брой, публикациите притежават изключително значима информация за художествените, културните, педагогическите, психологическите - човешките щрихи от биографиите на Галина и Стефан Йорданови.

\section{1. УтвържАаването на граА Варна като международен фестивацен центьр}

Периодът от 1960 до 1980 година се характеризира с утвърждаване на граА Варна като фестивален центьр. Съществено постижение, което и Ао Анес 
определя облика на Варна като фестивален граА, е Международният музикален фестивал “Варненско Аято”. Той е пулсиращото сърце на Аятната културна столица, неговата мисия е Аа бъде “прозорец към света". Към тази метафора можем да добавим, че фестивальт е “прозорец и на света” към българската певческа, танцова, филмова, актьорска изява. "В този пьрви етап до 1967 г. пише музикалният критик Розмари Стателова - "Варненско цято” разчита в сериозната си част, както вече бе казано, на Варненската народна опера... Въобще 1961 г. е върхова за варненската оперна фестивална изява през този етап. Репертоарьт е разнообразен: “Аида", “Аон Карлос", "Риголето", “Трубадур”, “Травиата”, “Ернани”, “Бохеми”, “Тоска”, “Кармен”, “Така правят всички” /Моцарт/, “Имало едно време”... Впечатляващ е съставът на гостуващите изпълнители: Елена Николай, Зинаида Пали, Никола Николов и Ар. Гастролират победителите в току-що проведения Първи межАународен конкурс за млади оперни певци: Питьр ГАосоп, ВАадимир Тимохин и Ар., както и наградените варненски участници: Маргарита Аилова, Стефан Циганчев, Георги Койчев, Тодор Костов. Все според редакционната статия на “Нарона култура”, “с право може да се каже, че в тазгодишното пето мято изкуството на талантливата певческа младеж от редица страни намери широко поле за изява". СлеА като посочва заслугите на Аиригентите Й. Йосифов, Б. Чирпански и Н. Недялков, режисьорите Н. Николов, Ар. Кърджиев и Ар. Мицов, както и балетмайсторите Галина и Стефан Йорданови, вестникът на свой ред поставя проблема “Аетен театьр” (Стателова, 1996:92). Проблемите на варненския $\Lambda$ етен театьр не слизат от Аневния реА на организаторите и управ яващите културата. За нас е важно, че именно Аетният театьр става творческа територия благодарение на Галина и Стефан Йорданови, превръща се в ембблематичното пространство на световно балетно състезание - на първия по рода си МежАународен балетен конкурс. Вестник "Народна култура" наблюдава, отразява, стимулира утвьржАаването на МежАународния музикален фестивац “Варненско мято", който се обогатява с МежАународния балетен конкурс. Кореспонденция на варненския журналист главен редактор на вестник “Народно дело" Е. Аекало във вестник "Работническо дело” ни въвежда в амбициите на варненската културна общественост Аа се разширява и обогатява профила на Фестивала “Варненско мято”. Авторьт на публикацията вижАа в Първия межАународен балетен конкурс, централно събитие на фестивала, който нареА с филмовото изкуство, Аругият център, ще бъде приАружаван от проявите на театралния жанр и художествената самодейност - в Аицето на “Празника на песните и танците”. На финала Е. Аекало заключва: 
“Бъцгарският цирк ще вземе значително по-голямо участие, отколкото в минацото.” (Как ще се проведе тази година „Варненско мято”, 1964:3)

В статия озаглавена “Балетният конкурс трябва да стане традиция" голямата кубинска прима балерина Алисия А^онсо подкрепя и насърчава трайното присъствие на Международния балетен конкурс в културния календар на Варна (Народна култура, 1964:3).

За да подкрепя, значителната роля на Галина и Стефан Йорданови за развитието на балетното изкуство в България и международния им принос към световното балетно изкуство, ще цитирам част от еАна публикация на Светла Трайкова.

“ЕАно от събитията, които отрежАат място на България и на Варна в хилядолетната културна история, е провеждането през 1964 година на първия в света международен балетен конкурс с двадесет и две издания до Анес. Изненадващото е, че малка Аържава като нашата, без Аъцголетни традиции в балетното изкуство, става инициатор на такава културна изява, която събира балетни педагози, хореографи и изпълнители от цял свят.

Въпросът е не толкова за първите организатори на конкурса, колкото за първите инициатори и мястото на неговото провежАане. АалновиАна е иАеята граА като Варна - отворен към света, с прекрасни природни Аадености, с великолепна мятна сцена и силно желание да се превърне в място на благородно състезание - Аа покаже, че изкуството на танца е общуване без граници в един хармоничен свят без разделения, въпреки “желязната завеса" и студената война между Изтока и Запада. Първият председател на журито великата Галина У манова, възкииква:

“Бъцгария е малка страна, но с голяма инициатива!” (Трайкова, 2008)

Периодът 1960-1980 година е интересен и поради факта, че именно през този период през 1966 година Варненската общественост успява да постигне подкрепата на ЦК на БКП, по-конкретно с решение на Секретариата на ЦК на БКП и с Министерско постановление "Варненско мято” придобива статут на първия български межАународен фестивац, регламентиран като международен и представителен.

\section{2. ЗаражАане на професионалното танцово образование във Варна}

Балетното образование в България закъснява чувствително в сравнение с театрацното, музикалното и образованието в областта на изобразителните изкуства. През 1950 година е създадено Аържавно балетно училище, от 1956 става Аържавно хореографско учикище. 
ИАването на Галина и Стефан Йорданови във Варна напомня ситуацията в Бъцгария в началото на XX век, когато при отсъствие на висши училища българи завършват в утвърдени европейски университети, за Аа се върнат в България и с възрожденски ентусиазъм да направят така, че да се преодолее закъсняването спрямо европейските култури. Школата на руския балет е школа и за балетни педагози. Това потвържАава и Ивайло Иванов в монографията му “Техники на танца“" "Важно за по-нататьшното развитие на обучението по танц в Бъцгария е обстоятелството, че почти всички негови значими дейци черпят знания от възможно най-добрите школи от Централна Европа и емигриралите от Русия представители на балетното изкуство по това време. Неслучайно повечето от тях по-късно се налагат като забележителни балетни педагози" (Иванов, 2020:40-41).

Галина и Стефан Йорданови са инициатори на първото извън столично професионално балетно образование. Откриването на експериментален кцас към Аържавното хореографско училище в София, а по-късно и клас към НУИ “Аобри Христов” във Варна им е коствало много упорита борба, но все пак те успяват. Анес във всички по-големи градове на страната - Пцовдив, Русе, Бургас, Стара Загора, в училищата по изкуствата вече има и балетни класове.

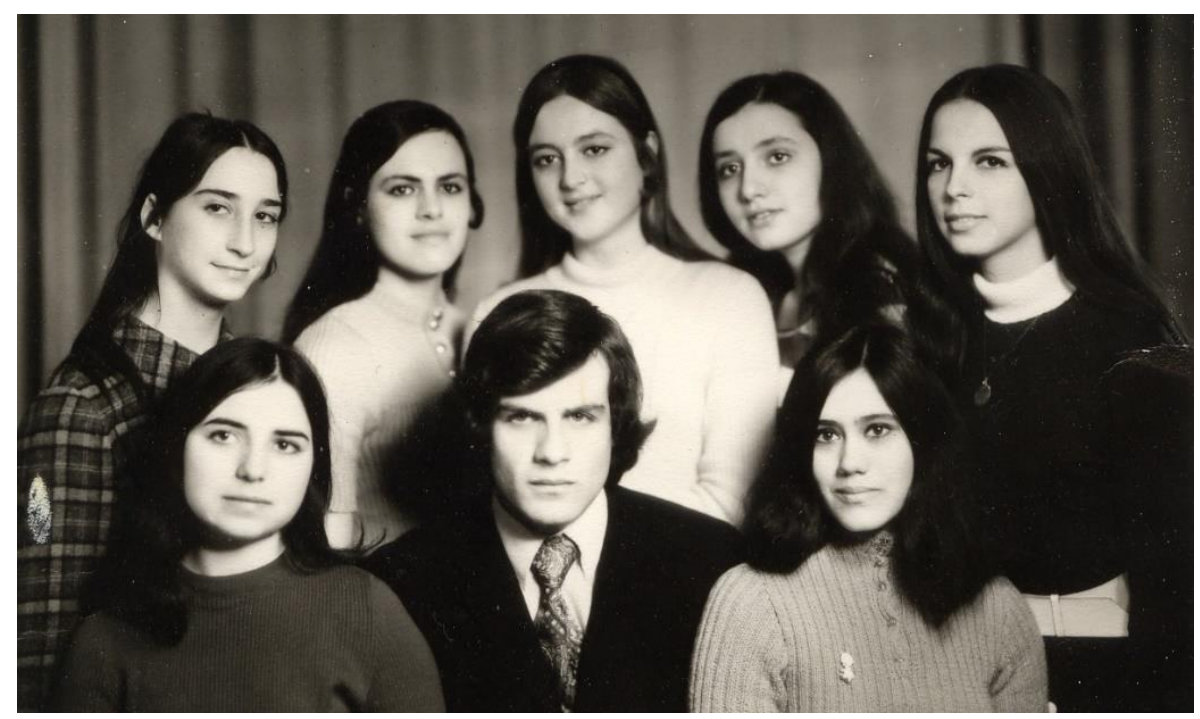

И^юстриране 1. На снимката са завършващите абитуриенти: отАяво надясно отзад: Татяна Чендова, Керанка Николова, Златинка Минчева, Жулиета Велинова, Аарина Халачева отпреА: Антоанета Белчева, Константин Илиев, Красинка Маркова

Балетната школа във Варна е основана през 1954 година. Тя изгражда своята работа върху програмата на кръжоците по хореография, без да си 
поставя за цел подготовката на професионални кацри. През цятото на 1960 г. Галина и Стефан Йорданови поставят на нови основи заниманията в балетната школа. Тяхната цел е създаването на млади кадри, които непрекъснато Аа обновяват основния балетен състав при операта. Внимателно, стьпка по стьпка напреА по пътя на трудното, но прекрасно изкуство, водят своите ученици двамата педагози. Те са уббедени, че всичко зависи от волята и упоритостта на ръководителите, но и работата и постоянството на учениците.

А Галина и Стефан Йорданови са много упорити. През 1966 г. се открива за първи път експериментален клас по балет.

“В края на миналата година във Варна се откри експериментален клас по балет - филиал на Аържавното хореографско училище в София. Хубава инициатива, осъществена от балетмайсторите на Варненска народна опера Галина и Стефан Йорданови. ЕАно Аоверие към техните педагогически и високи професионално-естетически качества.

Своята идея за откриването на таквв клас Стефан Йорданов обосновава по следния начин:

"Варненската опера тряббва Аа стане представителна. Това ще бъде възможно, когато всичките и́ подразделения станат представителни. За това е

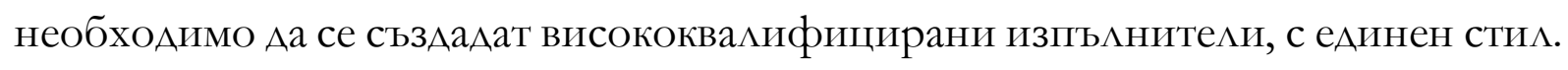
Световна традиция е големите оперни и балетни театри Аа имат собствени студия - училища за подготовка на каАри.

Освен това с провеждания тук Международен балетен конкурс Варна се утвърди като световен балетен центьр. Това завоевание трябова Аа се защити със завидна балетна култура. А и новата опера ще повиши броят на балетните спектакли. Това налага Аа се увеличат добрите балетисти - местни кацри. Практиката показва, че не може Аа се разчита на разпределените за Аве години възпитаници на Аържавното хореографско училище, които обикновено напускат след изтичане на определения срок.

През Аеня учениците от класа по балет посещават занятията в различни общообразователни училища, а вечер 15-те поклонници на Терпсихора трьгват по пътя на своите мечти. Заниманията се водят по програмата на Аържавното хореографско училище - София: изучават практически и теоретически балетното изкуство, пиано и актьорско майсторство. СлеА завършване на четиригодишния курс получават диплом за правоспособни балетисти. Такъв експериментален к^ас за първи път е открит в провинцията, затова носи и такова име. Необходимо е варненската културна общественост 
да подпомогне осезаемо тоя опит и той да се превърне в традиция.” (Увалиев, 1967)

УбеАително звучат аргументите на журналиста, в подкрепа на споделената илея на Ст. Йорданов, за да бъдат адресирани към “варненската културна общественост”, която трябва “Аа подпомогне осезаемо тоя опит и той Аа се превърне в традиция".

През тези години успоредно с работата на експерименталния клас те продължават да развиват и дейността си в студията към операта. Ето какво споделя Стефан Йорданов в статията на журналиста Ст. Венецианов под заглавие "Урок по изящество":

“Аетско-юношеската балетна студия към операта има за цел да открива и подбира способни деца, Аа ги обучава и подготвя. Най-изявените от тях слеА време постьпват в експерименталните класове на филиала към Аържавното балетно учимище открит във Варна. Аецата (повече от 90) посещават сбирките с голямо желание и изучават само специални балетни дисциплини. В рамките на занятията от един академичен час те усвояват основите на класическия танц. В учебните им уроци намират място и занимания с характерни народносценични и историко-битови танци, както и основни принципи на актьорското майсторство. ГАавното ядро на тези кцасове са момиченцата. Но желанието ни е да се увеличат и момченцата. Струва ми се, че е време Аа се скъса с отживе иия предразсъдък, че това изкуство не е толкова за мъже, защото в него няма мъжественост! В заключение трябва да кажа, че голяма част от бившите възпитаници на школата сега са артисти в нашата опера, а много от тях са межАу първите сили на театрите в Русе, Стара Загора, Пцовдив...” (Венецианов, 1968).

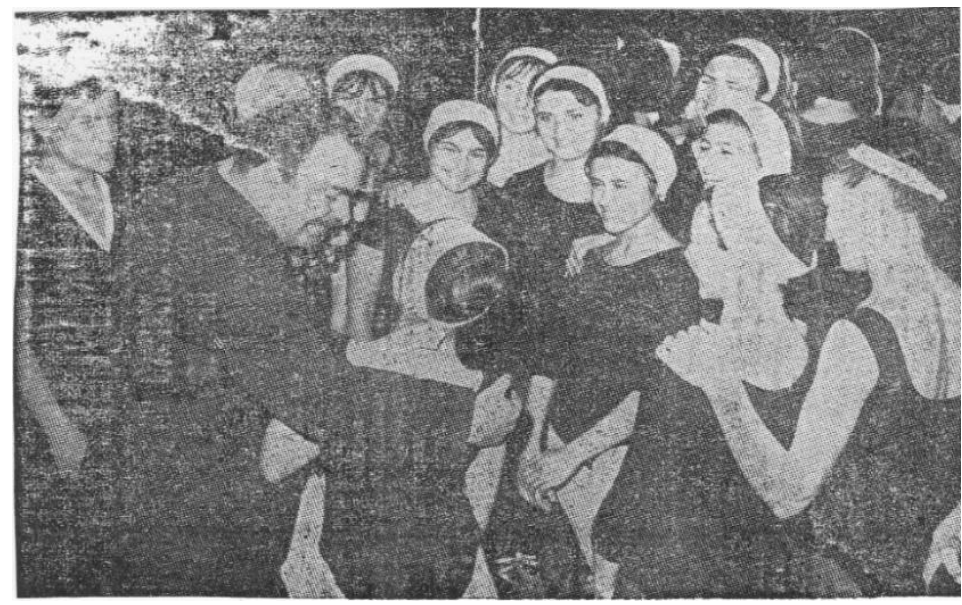

И^юстриране 2. Стефан Йорданов с възпитаници на Аетско-юношеската балетна студия към операта 
Каква е същността и какви са перспективите на този експериментален клас? - такъв беше въпросът ми към балетмайстора Ст. Йорданов:

- От миналата година нашите възпитаници са същевременно ученици в Музикалното училище “А. Христов”, където изучават общообразователни Аисциплини и получават нужната музикална подготовка. Когато завършат училището, към оценките от изпита по балет ще се прибавят и Аругите оценки и те ще получат и диплома за завършено хореографско училище. По всяка вероятност Аогодина ще се обособи специален балетен отдел към Музикалното училище...

- Извинете, защо наричате този клас експериментален?

- За първи пьт в страната сформирахме такъв клас, в който за 4 години вместо за 9 (както е в хореографското училище), по специална програма, изработена от нас, се подготвят балетни кадри.

Не го попитах Аали е изАязъ у успешен този експеримент. Художествените изяви на младите балетни артисти на варненска сцена са красноречиво доказателство за това.” (Терзиева, 1970)

Венета Терзиева успява Аа документира един разговор, който само на пръв поглед изглежАа обикновен. Няма Аа е за първи път, нито за последен “гасенето на ентусиазма" в областта на художественото образование във Варна, и все поради една и съща причина - асиметрията межАу професионализма и неговата изпреварваща с Аесетилетия визия и менивото късогледство на чиновниците, които “чинно” следват хода на обичайното време. Може само Аа се уважава еАна журналистика, която следва творческата амбиция, изпреварва и води не само читателите, но се опитва да убеждава и "варненската културна общественост."

През 1971 г. този клас е закрит. ЕАва след четири години във Варна към АМУ “А. Христов” отново е открит експериментален балетен клас, който Стефан Йорданов се надява Аа прерасне в балетно училище и Аа се реши пробоема с калрите в Североизточна Бъмгария.

Прилагам авторската статия на Стефан Йорданов поместена в в-к "Народно Аело” по повод професионалното балетно образование във Варна.

“Аа се утвврждава гледището, че Варна би могла да бъде средище на професионално балетно образование, е и леко, и трудно. Защото твърде много са сериозните балетни ироблеми у нас, а някои от тях - все още спорни". 


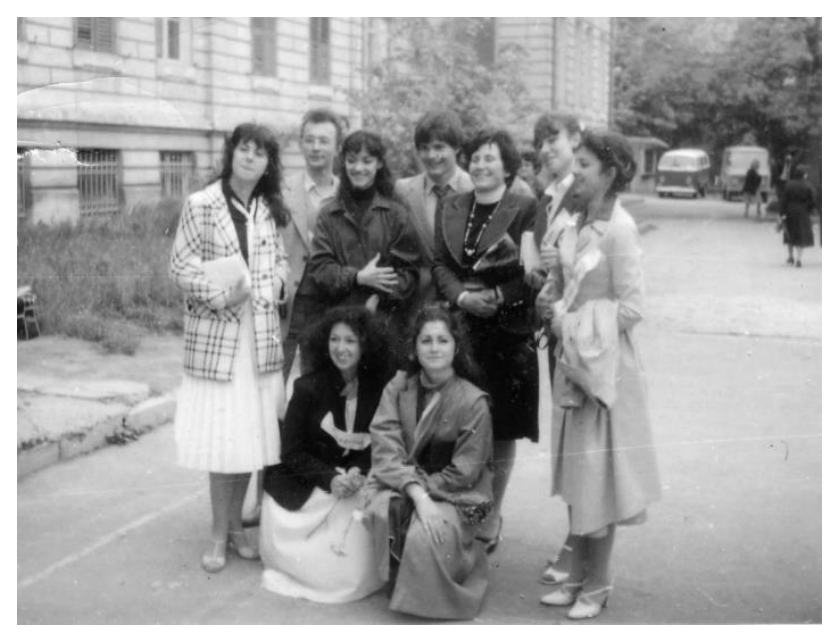

И^юстриране 3. II експериментален балетен клас към СМУ “Аобри Христов” - Варна, випуск 1975-1980 г. Снимка на класа в училищния двор с класната ръководителка Вилка Христова /учителка по история/.

Аз нямам за цел да се спирам на особеностите и същността на тези проблеми. Ще ми се обаче да отАеля главния от главните сред тях - системата и практиката на професионалното балетно образование.

В чужбина то е възникнало отдавна, усъвършенствацо се е заедно със сценичното танцувацно изкуство, когато бацетните състави са се изграждали като самостоятелни творчески колективи. И още тогава в редица западноевропейски страни и в Русия се дошло до убеждението (проверено от няколко вековната практика), че най-полезното и плодоносно е балетните училища и школи да се изграждат към действащите оперно-балетни театри, като се свързват организационно и творчески със “своя” театьр, за който Аа се създават необходимите млади професионални артисти.

Не може да не съжацяваме, че българската буржоазия не ни остави даже и зачатьк на традиция в професионацното бацетно образование, осъществявано преАи не от обществено-държавни усилия, а от частно-мениАжърска инициатива на отАелни мица.

Видимата полза от възпитанието на млади балетни изпълнители от Аържавното хореографско училище в София, съществуващо вече 25 години, не може да потули истината, че за тоя срок то не задоволи нуждите на опернобалетните театри от млаАи изпълнителски каАри. Балетните състави в провинцията не биха могли да разчитат на неговите възпитаници и в случай, че обемът на класовете в училището бъде неколкократно увеличаван, в противоречие със спецификата на методическите изисквания. 
Преди известно време насъщната нужда от балетни изпълнителски каАри застави рьководството на Варненската народна опера Аа потьрси подкрепата на обществеността и държавните институции в София и Варна, за да подпомогнат създаването на балетен отдел към Аържавното музикално училище “А. Христов”, като филиал на Аържавното хореографско училище в София. ЗаАачата беше Аа се набират периодически, в зависимост от нужАите, учебни класове, в които се обучават и възпитават млади балетни артисти. Беше създаден само един експериментален клас, който действително позволи Аа се експериментира най-полезната бъдеша форма на професионално балетно образование в нашия граА. За резултатите от работата в тоя кАас говореха ежедневните оценки на успеха по специалните балетни предмети, които винаги го определяха като клас-първенец на Аържавното хореографско училище. Експериментьт потвърди два обективни извода: първият от тях бе, че при условията и базата, които предоставят Аържавното средно музикално училище и Варненската народна опера, може успешно, с много Аобри резултати Аа се подготвят професионални балетни артисти. Вторият извод бе, че най-подходящата учебно-методическа и административно-организационна форма за подобна дейност може Аа бъде балетния отдел към Музикалното училище, в който Аа се набират, в зависимост от нужАите, както експериментални класове - със ськратен срок на обучение, така и редовни за млади балетни артисти.

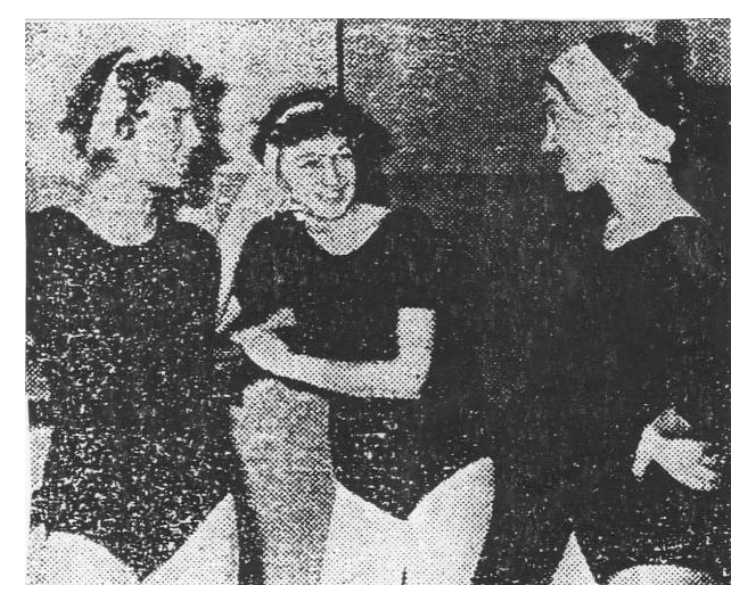

ИАюстриране 4. Ученици от експерименталния клас във Варна

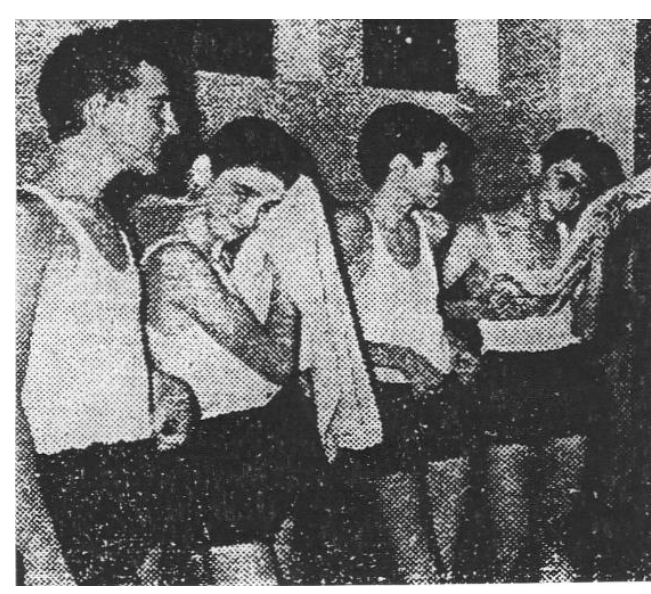

И^юстриране 5. Бъдещите балетни артисти от експерименталния кцас във Варна

Решението на комитета за изкуство и култура Аа се открие отново един експериментален клас във Варна ще осигури частично решаване на 
репертоарните, кацровите и Аруги проблеми на операта и балета във Варна. Не е Аалеч деня, когато градът ще разполага с великолепна самостоятелна оперна сграда. Тогава и задачите, които ще се поставят преА балета, ще бъдат помащабни, а нуждите на фестивалите, на международния балетен конкурс, на богатия културен живот на града - по-големи. И ако трябва да тьрсим успех при разрешаването на комплексните балетни проблеми във Варна, Аействителен принос може Аа Ааде укрепването на балетен отАел към Музикалното училище от експериментални и реАовни класове с пълен курс на обучение.

Така Варна ще се превърне в средище на професионално балетно образование!” (Йорданов, 1975)

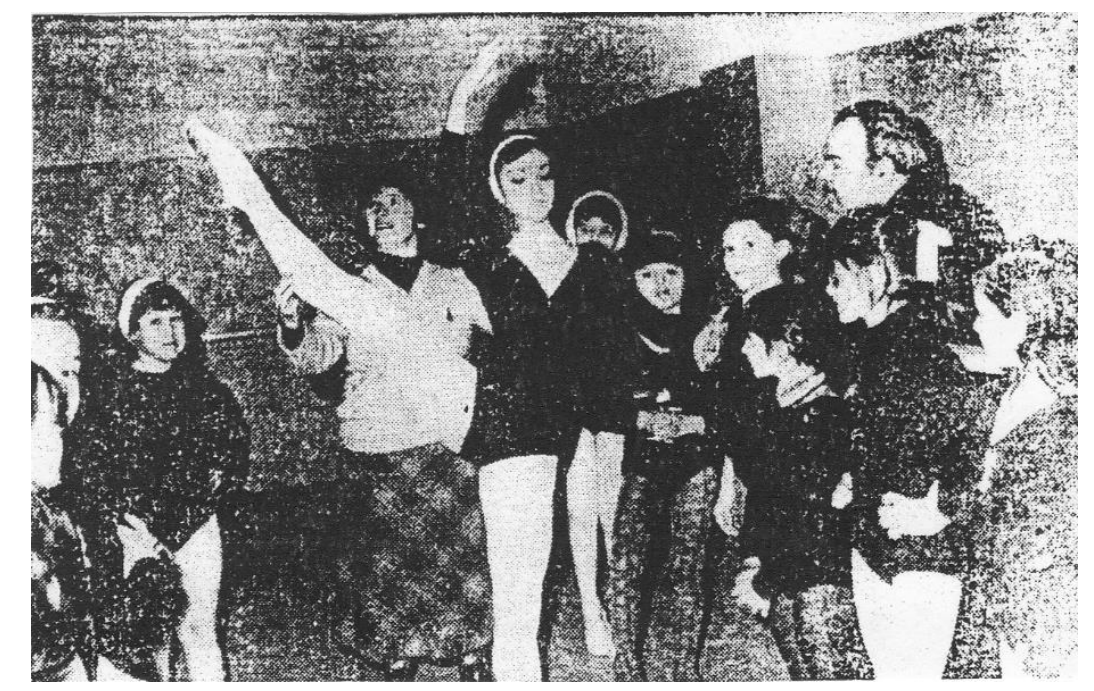

И^юстриране 6. Галина и Стефан Йорданови по време на занимания

Ето и еАно интервю поместено в регионалната преса, в което Стефан Йорданов защитава тезата си за необходимост от балетно образование във Варна.

Провокиран за проблемите с които трябва постоянно Аа се преборва, Стефан Йорданов каза:

- За да съществува пълнокръвен, резултатен, плодоносен хореографски живот, ние трябва да възпитаваме повече талантливи кацри. А за да стане това е необходимо Аа имаме различни балетни центрове. Още като един от първите педагози в новооснованото балетно училище в София през 1949 година вижАах и твърАях, че то не е достатьчно да отговори на нужАите на всички оперни театри в България. Направихме опити с отАелни експериментални 
класове към Музикацното учицище, но не съм удовлетворен, защото смятам, че трябва да съществува едно постоянно балетно отделение, а не епизодични възможности! Имаме достатьчно балетни зали, които обслужват балетния конкурс, имаме и педагози, сигурен съм, че ще израснат и нови, съществува оперен театър, в близост са Бургас и Русе, където ще поемат част от кадрите, подготвени в евентуален варненски балетно-педагогически центьр. Но се проявява мудност в решаването на този проблем.

- Какво е необходимо да се направи от окръжния съвет за култура, пък и от страна на новосъздадените районни съвети за култура?

- И много, и малко. Многото е, че трябва да се преодолеят недоверието, инерцията, страхът, че ще се подготвят изАишни каАри. Практиката показва, че редица щатни бройки в Бургас, Русе, Стара Загора, Пловдив, Плевен са незаети поради мипса на балетисти. Във Варна обществеността е съдействаца за създаването периодически на класове, които се водят към профкомитета на операта, но те имат редица недостатьци: децата плащат такса, приемаме голям брой от кандидатите, защото класовете трябва да бъдат “рентабилни” - грижи за отопление, осветление, почистване... Експерименталният клас към Музикалното училище има абсолютно същата програма като редовните класове в Балетното училище в София, но проблемът е Аруг: ние набираме една паралелка, която минава пет годишното обучение - от осми Ао Аванадесети клас. А възпитанието на младия балетен артист зависи много от възрастовите етапи, от чисто физиологическото му развитие. Методиката отчита особеностите на тези възрасти. Във Варна не можем Аа създадем редовни класове към Музикалното училище и по този начин сме Аишени от възможността да въздействаме в най-решителните етапи за пластическото развитие на детето, когато то трябва Аа танщува не по 45 минути всеки Аен, както е в школата, а часове наред по определена програма. Сега започваме след седми клас, по средата на пубертета и започваме със закъснение Аа се намесваме и въздействаме върху особеностите и спецификата на всичко онова, което вече се е проявицо като структура и даденост ... Така процесът на възпитанието сериозно се затруднява ...

- Споделям неговите тьрсения, още от времето, когато бяхме студенти вкцючва се активно в разговора Галина Йорданова. Затова и решително промених живота си като дойлох в България. Във Варна ни покани тогавашния Аиректор на операта Емил Трифонов, който ни създаде условия за плодотворна работа. Много от нашите възпитаници отидоха в София, затова замислихме да създадем местни кадри, които периодически Аа попълват 
състава - първоначално той беше едва от 18 души... Целта е млаАите балетисти не само да разбират нашата методика, а и да свикнат с нея така, че когато дойдат в театъра да влязат в един колектив на единомишленици. ЕАиномислие, еднаква естетическа платформа - известно е още от Аревността, че найдобрият театьр се прави така.

- Вие сте интересни педагози. Наблюдавах ви как работите. Вие учите децата на точност и прецизност. Поощрявате ги да импровизират ...

- Смятам, че това е много важен момент във възпитанието на бъдещия балетен артист - обяснява Стефан Йорданов - Така се разкрепостява порива към собствена изява. Аа се импровизира по дадена тема - често използваме този похват, защото дава на децата възможност да фантазират, т.е. Аа творят, проверяваме у кое дете има този свещен огън - наречен талант. А не у всеки го има ...” (Аолапчиева-Сотирова, 1980)

\section{Аискусия}

Настоящото изследване на зараждането на обучението по танцово изкуство във Варна поставя проблема за постоянното състояние на преход на българската образователна система. Тази основна характеристика на актуанната система на българското образование намира ярко отражение в обучението по танц. С въвежлане на промените в ЗАКОНА за предучилищното и училищното образование през 2016 г. и новите стандарти се налага необходимостта от актуализиране на учебните планове и учебните програми. Това поставя на преден план въпросите:

- Каква е съвременната ситуация в образованието по танцово изкуство в

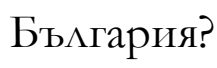

- Кои са най-съществените Аефицити, чието преодоляване налага повишено внимание както в областта на теорията, така и на педагогическата практика?

- Какви са основните приоритети очертаващи иновативните методи на преподаване и учене?

Несъмнено основополагаща роля във формулиране отговора на тези въпроси има изследването и реконструирането на историята на танцовото обучение в системата на средното образование в България, както и проучването и анализирането на методическите и творчески тьрсения на инициаторите. Направените заключение ще очертаят перспективата и посоката за развитие на обучението по танцово изкуство в Бъцгария. 


\section{Закиючение}

За успешната педагогическата дейност на Галина и Стефан Йорданови основен източник на информация остава периодичния регионален печат от 1965 до 1985 година. Техните възгледи за развитието на танцовото обучение и методика се отразяват предимно от варненски журналисти. В опит за реконструиране на зараждането на художественото танцово образование във Варна не откриваме източници на информация в учебни програми, писани методики, архиви и Аруги носители с Аокументална и историческа стойност.

Целта на журналистите е те Аа предизвикат активността в диалога от страна на Ст. Йорданов и Г. Йорданова, да се съобразяват с насоката на техните размисли, намерения, проблеми. В статията на Стефан Йорданов е споделена професионално обоснована програма за развитието на балетното образование в граА Варна. Тези материали документират културната мисия на твореца хореограф и балетен педагог, идентификация на неговото “варненско жителство” и “индивидуално битие”. Макар и не много на брой, публикациите притежават изключително значима информация за художествените, културните, пеАагогическите, психологическите - човешките щрихи от биографиите на Галина и Стефан Йорданови. Тези щрихи се пазят и от техните възпитаници, на експерименталния балетен клас, отново с амбицията Аа бъде първи извън столичен. Но Аокументирано е единствено публикуваното във вестник “Народно Аело”. В цялостното реконструиране на историята на художественото танцово образование във Варна с автентичността на споделените идеи, тези материали могат Аа послужат за източници на една съществена част от ненаписаната история. Материала е част от цялостното изследване на обучението по танцово изкуство в сферата на средното образование в Бъцгария.

\section{Признателност}

Използван е снимков материал, предоставен от мичния архив на $A$-р Светла Трайкова и от в-к “Народно дело”.

\section{Използвани източници:}

Венецианов, Ст. (1968, 8 декември). Урок по изящество. Народно дело, 288. Варна.

Аолапчиева-Сотирова, М. (1980, 6 май). Не у всеки е този свещен огън. Народно дело, 73. Варна. 
Иванов, И. (2020). Техники на танща. Варна: Славена.

Йорданов, Ст. (1975, 23 ноември). Варна - центьр на професионално балетно образование. Народно дело, 228. Варна.

Как ще се проведе тази година „Варненско мято” (1964). Работническо дело, 90.

Народна култура, 28, 3. 11 юни 1964 г.

Стателова, Р. (1996). Аятото на бъмгарската култура. 70 години Международен музикален фестивал "Варненско лято”. Варна.

Терзиева, В. (1970, 15 март). И въздухьт сякаш танцуваше. Народно дело, 63. Варна.

Трайкова, Св. (2008). МежАународният балетен конкурс в граА Варна - танцово предизвикателство. Българската култура и европейският XX век. 16 лятна научна среща Варна 2008. Варна: Община Варна.

Увалиев, Н. (1967, 12 март). Най-младите. Народно дело, 61. Варна. 